\title{
Migration patterns of Hoopoe Upupa epops and Wryneck Jynx torquilla: an analysis of European ring recoveries
}

\author{
Thomas S. Reichlin · Michael Schaub • Myles H. M. Menz • \\ Murielle Mermod - Patricia Portner · Raphaël Arlettaz • \\ Lukas Jenni
}

Received: 10 January 2008/Revised: 24 October 2008/Accepted: 27 October 2008/Published online: 26 November 2008

(C) Dt. Ornithologen-Gesellschaft e.V. 2008

\begin{abstract}
For many bird species, recovery of ringed individuals remains the best source of information about their migrations. In this study, we analyzed the recoveries of ringed European Hoopoe (Upupa epops) and the Eurasian Wryneck (Jynx torquilla) from 1914 to 2005 from all European ringing schemes. The aim was to define general migration directions and to make inferences about the winter quarters, knowing that hardly any recoveries are available from sub-Saharan Africa. For the autumn migration, there is evidence of a migratory divide for the Hoopoe in Central Europe, at approximately $10-12^{\circ} \mathrm{E}$. Autumn migration directions of Wrynecks gradually change from SW to SE depending on the longitude (west to east) of the ringing place. In both species, only a few recoveries were available indicating spring migration directions, but they showed similar migration axes as for autumn migration, and hence no evidence for loop-migration. Due to a paucity of recoveries on the African continent, we can make only limited inferences about wintering grounds: extrapolating migration directions are
\end{abstract}

Communicated by F. Bairlein.

T. S. Reichlin $(\bowtie) \cdot$ M. Schaub · M. H. M. Menz ·

M. Mermod · P. Portner · R. Arlettaz

Division of Conservation Biology,

Institute of Ecology and Evolution, University of Bern,

Baltzerstrasse 6, 3012 Bern, Switzerland

e-mail: thomas.reichlin@nat.unibe.ch

T. S. Reichlin · M. Schaub · L. Jenni

Swiss Ornithological Institute, 6204 Sempach, Switzerland

R. Arlettaz

Swiss Ornithological Institute, Valais Field Station,

Nature Centre, 3970 Salgesch, Switzerland only indicative of the longitude of the wintering area. The directions of autumn migration indicate a typical pattern observed in European long-distance migrants: west-European Hoopoes and Wrynecks are likely to winter in western Africa, while central- and east-European birds probably winter more in the east. Due to the migratory divide, for the Hoopoe, this phenomenon is more pronounced.

Keywords Connectivity $\cdot$ Jynx torquilla $\cdot$ Migration . Ring recoveries $\cdot$ Upupa epops

\section{Introduction}

Thanks to bird ringing over the past 100 years, we have gained a lot of insight into the biology of birds, especially for seasonal movement patterns (Bairlein 2001). Historically, the main interest of bird ringing was to describe migration routes and wintering ranges. Today, ringing data play a key role in many studies on ecology, behaviour, population dynamics and conservation of bird populations (Baillie 2001). The conservation of migratory bird species involves not only protecting crucial habitats in the breeding areas, but also on the wintering grounds (e.g. Pain et al. 2004; Holmes 2007; Walther et al. 2007). It is thus essential that we have as much information as possible on the spatio-temporal whereabouts of a species (Webster et al. 2002).

For many European migratory species, the breeding habitat and distribution ranges are well described and compiled in various handbooks (e.g. Cramp 1985; Glutz von Blotzheim and Bauer 1966; BirdLife International 2004). On the other hand, the non-breeding distribution is much harder to assess (Bibby 2003), as species might be very elusive, or simply because they are visiting regions where bird watchers 
and ornithologists are rare. Nevertheless, handbooks do contain broad descriptions of a species' wintering distribution, based mostly on observations. In most cases, we lack information about the connectivity between breeding grounds and wintering areas (Webster and Marra 2005), as well as which flyways different populations use when migrating southwards. Consequently, the wintering areas of many European long-distance migratory bird populations cannot be described as accurately as the breeding areas. In many cases, ringing has to date yielded insufficient information to determine the wintering grounds for many species and populations (Szép et al. 2006). Although they may be scarce and have many drawbacks (e.g. Pfister et al. 1992; Gauthier-Clerc and Le Maho 2001), ring-recovery data are still among the most spatially accurate sources of information on migratory movement (Norris et al. 2006) and connectivity (Webster et al. 2002).

Many species migrating to sub-Saharan Africa fly through the western (Iberia) and eastern (Middle East) land masses of the Mediterranean, rather than crossing the central Mediterranean Sea. This entails a gradual change of migration directions from SW orientation in western Europe to SE orientation in the east, or sometimes a clear-cut migratory divide (Schüz 1964). Especially in the latter situation, this clearly points to different winter quarters in sub-Saharan Africa.

In this study, we examined the migration directions of two non-passerine birds, the European Hoopoe (Upupa epops) and the Eurasian Wryneck (Jynx torquilla) from recoveries of ringed individuals. The Wryneck and the Hoopoe are currently on the IUCN Red List in category SPEC 3 (moderate recent decline; IUCN 2001). For both species, no European-wide ring-recovery analysis is available. Hoopoes and Wrynecks are assumed to winter mainly in the Sahel Belt in sub-Saharan Africa and occasionally in the Mediterranean. A migratory divide was previously postulated for Wrynecks, but not for Hoopoes (Glutz von Blotzheim and Bauer 1966; Cramp 1985). The latter seem to cross the Mediterranean Sea along its whole width (Glutz von Blotzheim and Bauer 1966). We focus in particular on the migration directions during autumn and spring migration across Europe and re-evaluate whether there is evidence of a migratory divide. Based on the mean migration directions within Europe, we hypothesise about the possible wintering areas of both species with the goal of learning more about the connectivity of the European breeding populations.

\section{Methods}

From the EURING data base (European Union for Bird Ringing), we obtained recovery information on 117 Hoopoes and 331 Wrynecks spanning 92 years of ringing and recovery data (1914-2005). Because the EURING data base is incomplete, we added 16 Hoopoe and 12 Wryneck recoveries which are mentioned in the literature (Glutz von Blotzheim and Bauer 1966, and references therein) as well as three unpublished, recently reported Hoopoe and two Wryneck recoveries (Swiss Ornithological Institute, Sempach).

Birds were only included in the analysis if the recovery date was accurate to at least 2 weeks of either side of the recovery date mentioned in the raw data and if the accuracy of the ringing or recovery coordinates were within $50 \mathrm{~km}$ (Speek et al. 2006). We excluded all records with less than $100 \mathrm{~km}$ between the ringing and recovery sites in order to eliminate local, pre-migratory movements and returns to the natal area (e.g. birds roaming in the breeding area before leaving on their autumn migration). These selection criteria were more strict than in other publications and hence our recovery maps may exclude some recoveries published elsewhere (e.g. Saurola 1999).

Migration periods were defined according to Cramp (1985) and del Hoyo et al. (2001). Records were considered to reflect autumn migration movements if the birds were ringed between April and August and recovered between July and December (Hoopoe: $n=49$; Wryneck: $n=121$ ). Spring migration movements were defined by birds ringed in January to April, and recovered from March to July (Hoopoe: $n=30$; Wryneck: $n=30$ ). Records, which were not within these migration periods were excluded from further analyses. Additionally, we excluded records (Wryneck: $n=22$ ), which were considered to be uninformative regarding general migration movements. These comprised records that were attributed to natal/breeding dispersal.

Records of birds that were ringed and recovered in the same year provided the best spatial information on migratory movements, still keeping in mind that the true flight path is likely not a straight line. Recoveries made in a later year can provide information on migration under the assumption that birds are philopatric to the breeding/hatching and/or wintering area. Recoveries from later years are grouped in two categories: (1) records falling within the defined migration periods, but the recovery was made in a later year; or (2) records falling within the above defined migration periods, yet the area the birds are presumably migrating to is the ringing site (e.g. ringed in breeding area, recovered during the following spring; hereafter "inverse season"). In order to get comparable bearings between same year/later year and inverse season recoveries, the migration directions were transformed by adding $180^{\circ}$ to the calculated value.

Sex was not considered in the analysis, because in both species, sex is not easily assessed based on morphological characters. Migration patterns could potentially differ between age classes (e.g. Ketterson and Nolan 1983; Bairlein 2001); however, we did not include age in the 
analysis because we were primarily interested in general migration patterns and possible wintering quarters.

All analyses were performed with the statistical software package R (CRAN-The Comprehensive R Archive Network, Version $\mathrm{R}$ 2.6.1). Distance and direction were calculated using $\mathrm{R}$ codes obtained from http://www.oikostat. ch (Korner-Nievergelt 2004, after Imboden and Imboden 1972). Recoveries were depicted on Mercator maps where loxodromic distances are straight lines (constant directions; Imboden and Imboden 1972).

Rayleigh tests were used to check for a significantly preferred migration direction (Batschelet 1981). To test whether birds from different locations show different migration directions, we fitted a regression model for a circular dependent (migration directions) and a linear independent variable (longitude of ringing place). A Welch two-sample $t$ test was used to test for differences between the directions of birds ringed and recovered in the same year and birds ringed and recovered in later years. Statistics are presented as means $\pm 1 \mathrm{SD}$.

\section{Results}

\section{Hoopoe}

Mapping the autumn migration recoveries suggests a migratory divide running through Germany, Austria,

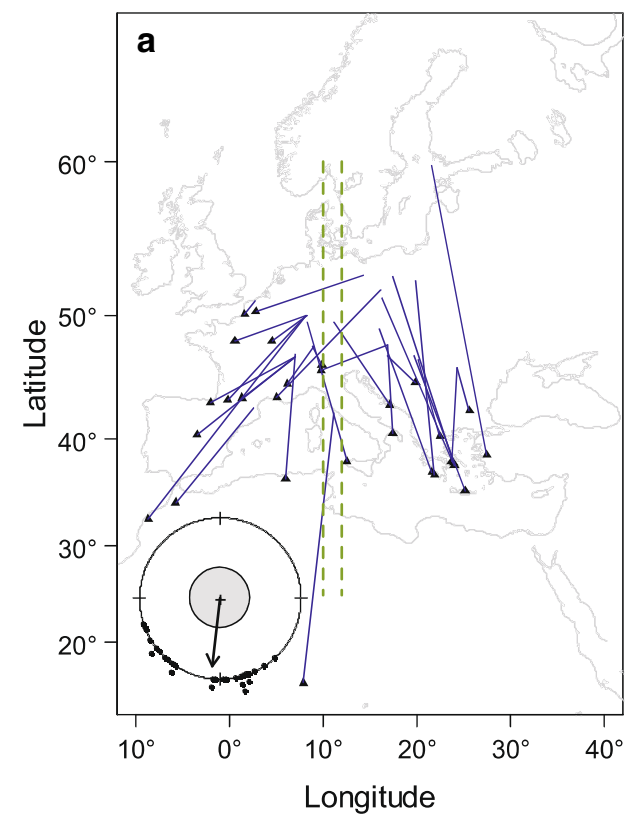

Fig. 1 Recoveries of European Hoopoes (Upupa epops) on autumn migration: a ringed and recovered in the same season $(n=29)$; b ringed and recovered in different seasons $(n=20)$. The dashed lines show a proposed migratory divide. Symbols indicate the recovery site. The small circle on the maps represents the result of the Rayleigh tests. The arrow indicates the mean migration direction of the
Switzerland, and Italy (Fig. 1a, b). Birds from these countries may, however, use either SE or SW directions. Only one individual was recovered in the described subSaharan wintering range (ringed on 19 April 1993 in Tuscany, Italy, reported dead on 1 November 1993 in Aderbissinat, Niger, distance 2,981 km). Table 1 shows the number of recoveries per ringing country grouped into geographic regions. The recoveries are from individuals ringed in western and central European countries, and are evenly distributed among these regions.

The mean direction for birds on autumn migration which were recovered in the same season was $193.7^{\circ}\left( \pm 34.8^{\circ}\right.$, $n=29$; Fig. 1a). The directions showed a bimodal distribution with two peaks at approximately $165^{\circ}$ and $225^{\circ}$. Directions were negatively related to the longitude of the ringing site (Fig. 2a). We achieved a good regression fit with the circular-linear regression model when both longitude and longitude squared were included in the model (longitude: estimate $=3.52, t=2.60, p=0.005$; longitude $^{2}$ : estimate $=-0.35, t=2.56, p=0.005$; Fig. 2a). Accordingly, a migratory divide can be set at $10-12^{\circ} \mathrm{E}$. Birds ringed west of this divide differed significantly in direction (207.4 $\pm 31.6^{\circ}, n=15$ ) from birds ringed east of the divide (178.7 $\pm 34.2^{\circ}, n=14$; Welch two-sample $t$ test with equal variances: $t=-2.34, d f=26.4, p=0.027$ ).

Autumn recoveries from a later year confirmed the pattern shown by same year recoveries (mean direction of $187.6 \pm 47.1^{\circ}, n=20$; Fig. 1b). The directions were,

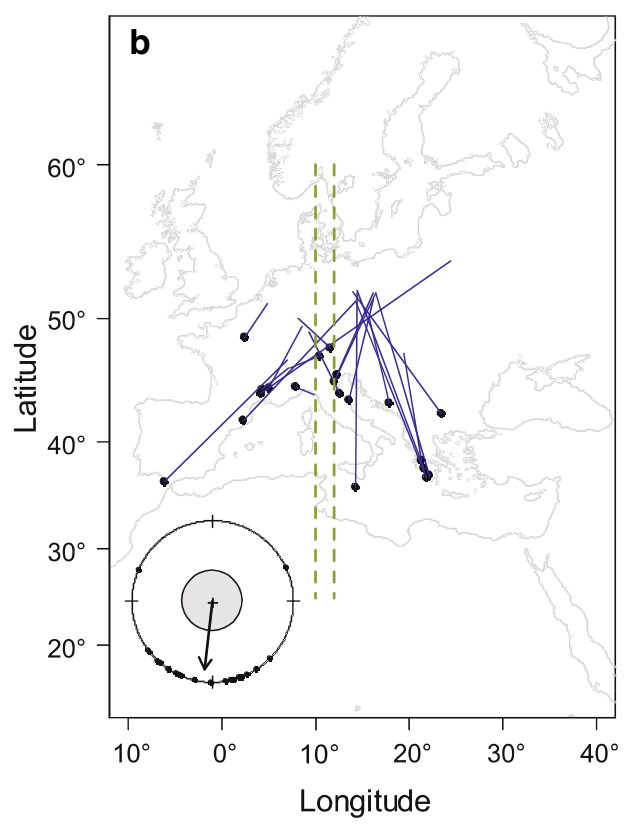

recovered birds. The length of the arrow is a measure of the mean vector length (test statistics of Rayleigh test 0.83 and 0.74 , respectively, $p<0.001$ ); it is inversely related to the variance of the migration directions. The inner circle indicates the $1 \%$ significance level of the Rayleigh test 
Table 1 Number of recoveries of European Hoopoes (Upupa epops) $(n=49)$ and Eurasian Wrynecks (Jynx torquilla) $(n=121)$ on autumn migration grouped into geographic regions of ringing countries

\begin{tabular}{lcc}
\hline Ringing country & Hoopoe & Wryneck \\
\hline Austria, Czech Republic, Hungary & 8 & 7 \\
Belgium, Luxembourg, Netherlands & 2 & 3 \\
Denmark, Finland, Norway, Sweden & 1 & 82 \\
France, Germany, Poland, Switzerland & 33 & 12 \\
Great Britain & 0 & 4 \\
Italy, Spain & 2 & 5 \\
Latvia, Lithuania, Russia & 1 & 6 \\
Romania, Serbia & 2 & 1 \\
Turkey & 0 & 1 \\
\hline
\end{tabular}

however, not significantly impacted by the longitude of the ringing place (circular-linear regression with longitude: estimate $=0.90, t=1.27, p=0.102)$. There was no statistical evidence that the autumn migration directions differed between same and different year recoveries (Welch two-sample $t$ test with equal variances: $t=0.49$, $d f=32.8, p=0.625$ ).

In general, Hoopoes showed similar routes in spring (Fig. 3) as in autumn. Only five recoveries could be attributed to spring migration during the same season (mean direction $47.5 \pm 42.2^{\circ}$ ) whilst four individuals were recovered in later seasons (mean direction $93.2 \pm 77.7^{\circ}$ ). However, because of the large scatter and small sample size, mean directions were not very informative. Birds ringed in the breeding area and recovered in a later spring (inverse season) were more numerous $(n=21)$. From these, we omitted recoveries $<400 \mathrm{~km}$ from the ringing site in order to ensure the exclusion of any breeding and natal dispersal. We obtained a transformed mean direction of $356.8^{\circ}\left( \pm 53.3^{\circ}, n=11\right)$. For all spring recoveries combined, mean direction is $24.6^{\circ}\left[ \pm 25.9^{\circ}, n=20\right.$ : spring same year recoveries (5) + spring later year recoveries (4) + spring inverse season recoveries $>400 \mathrm{~km}$ (11); Fig. 3]. There was no significant difference in mean migration axis between spring and autumn migration (all spring and autumn: Welch two-sample $t$ test: $t=0.80$, $d f=24.3, p=0.43$; all spring and same year autumn: $t=0.65, d f=25.6, p=0.52$ ).

Wryneck

Mapping the autumn migration recoveries did not result in a clearly visible migratory divide (Fig. 4). Four birds were recovered on the African continent (longest distance of $3,720 \mathrm{~km}$ for a bird ringed on 13 May 1989 on Gotland, Sweden, recovered dead on 15 October 1989 in Ifrhassene, Morocco), but none in the sub-Saharan winter quarters. Table 1 shows the number of recoveries per ringing countries grouped into geographic regions. It appears that many recoveries are from individuals ringed in Scandinavia, thus our inference may be biased towards these regions.

The mean autumn migration direction of birds caught in the same season was $205.8^{\circ}\left( \pm 21.0^{\circ}, n=83\right.$; Fig. 4a). Directions were significantly related to the longitude of the ringing site (circular-linear regression with longitude as variable: estimate $=0.71, t=5.14, p<0.001$; Fig. 2a). There was no indication of a step in the regression line, but a slight gradual shift from SW in western Europe to S directions in eastern Europe (Fig. 2b). Autumn recoveries from
Fig. 2 Autumn migration directions of birds ringed and recovered in the same season in relation to longitude of the ringing site: a Hoopoe $(n=29)$ : the step in the quadratic regression line indicates a possible migratory divide at ca $12^{\circ} \mathrm{E}$ (dashed line); b Wryneck $(n=83)$ : the line represents the circular-linear regression
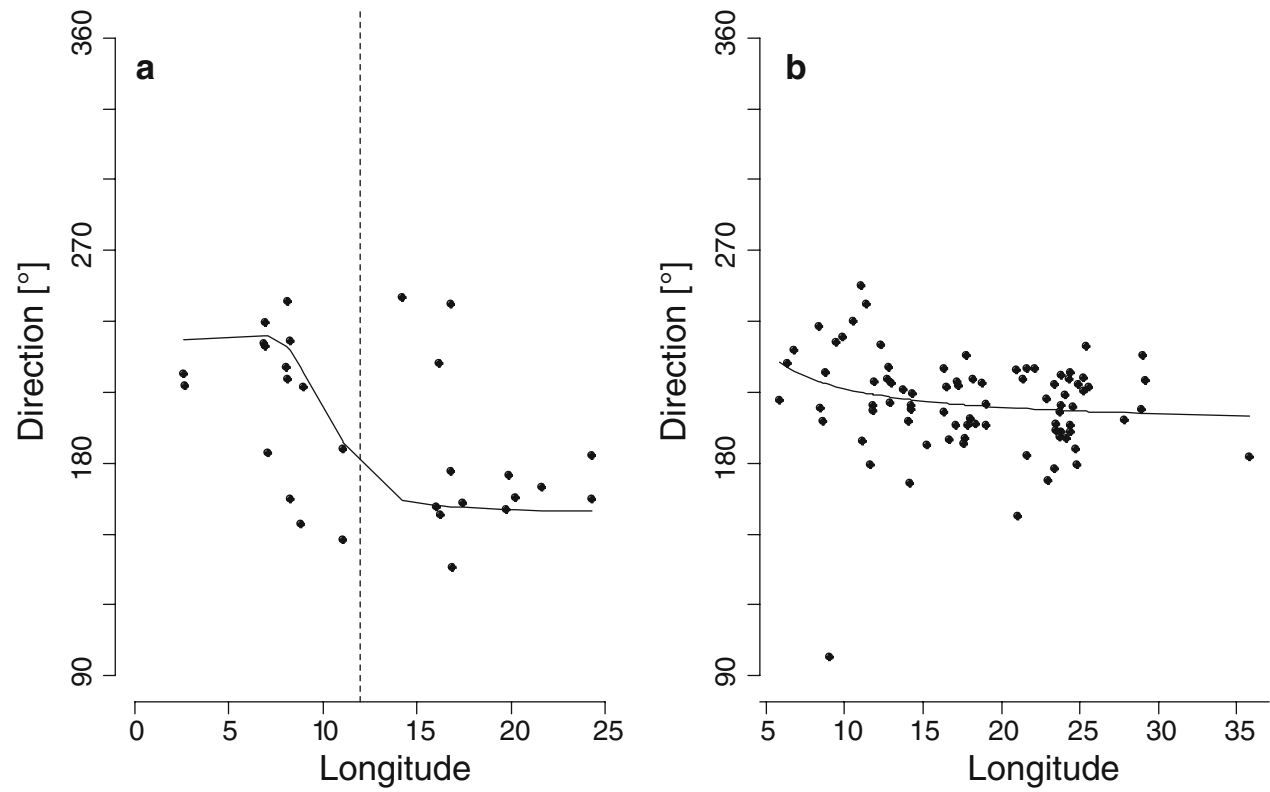


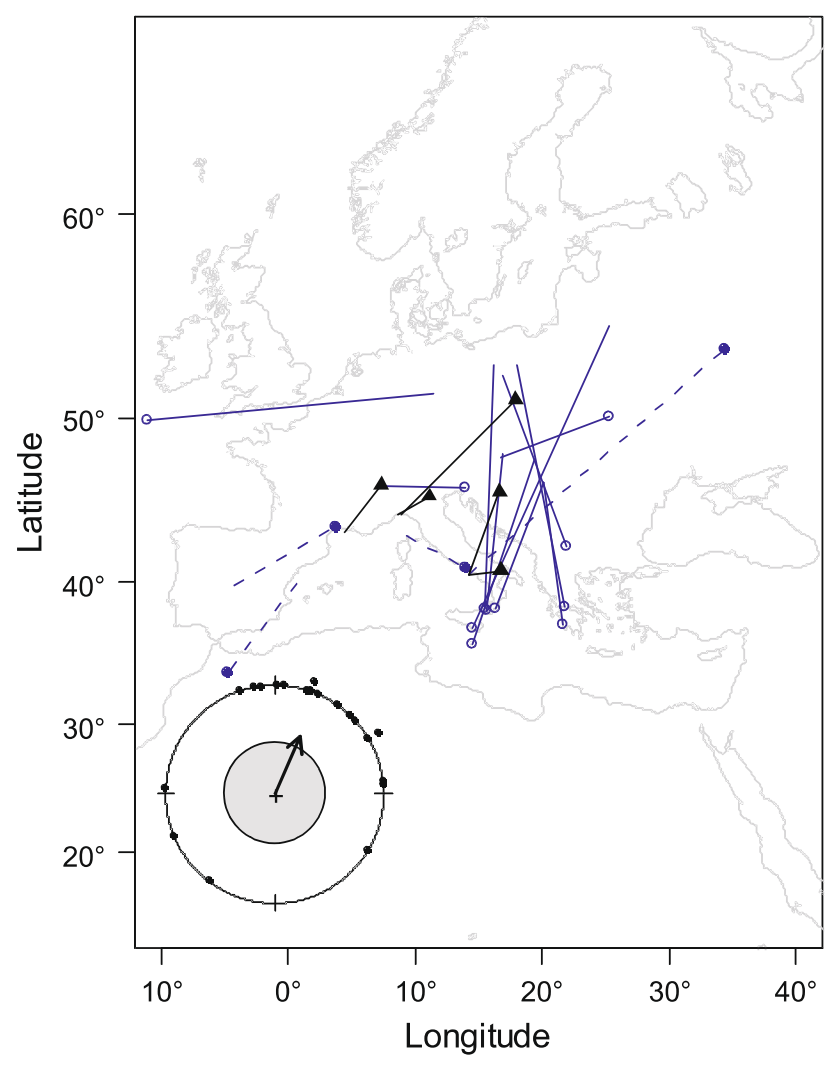

Fig. 3 Recoveries of Hoopoes on spring migration. Filled triangle birds ringed and recovered in the same season $(n=5$, solid lines); filled circle birds ringed and recovered in a later season $(n=4$, dashed lines); open circle birds recovered in a later season, yet attributed to inverse spring migration (only recoveries with $>400 \mathrm{~km}$ between ringing and recovery site, $n=11$, solid lines). Symbols indicate the recovery site. Test statistics of Rayleigh test 0.58 , $p<0.001$ later years again confirmed the pattern shown by same year recoveries (mean direction $209.8 \pm 55.5^{\circ}, n=38$; Fig. 4b). Direction was negatively related to the longitude of the ringing place (circular-linear regression with longitude: estimate $=0.01, t=3.00, p=0.001)$. We found no statistical evidence that the autumn migration directions differed between same and different year recoveries (Welch two-sample $t$ test: $t=-0.43, d f=41.9, p=0.67)$.

The migration routes of Wrynecks in spring (Fig. 5) are similar to those in autumn. Only seven birds were recovered within the same year (mean direction $26.4 \pm 150.5^{\circ}$ ) and just four individuals during spring migration of different years (mean direction $294.5 \pm 139.3^{\circ}$ ). Nineteen birds were ringed in the breeding area and recovered in spring (inverse season). From these, we again omitted recoveries $<400 \mathrm{~km}$ from the ringing site, due to the above-mentioned reasons. We obtained a transformed mean direction of $31.5 \pm 24.3^{\circ}, n=14$ ). For all spring recoveries combined, mean direction is $27.0^{\circ}\left[ \pm 114.8^{\circ}\right.$, $n=25$ (spring same year recoveries + spring later year recoveries + spring inverse season recoveries $>400 \mathrm{~km}$ ); Fig. 5].

The mean migration axis between spring and autumn migration did not differ significantly (all spring and autumn: Welch two-sample $t$ test: $t=-0.003, d f=27.8$, $p=0.98$; all spring and same year autumn: $t=0.10$, $d f=25.9, p=0.92$ ).

\section{Discussion}

This study is one of the few European-wide analyses of ring recoveries, as asked for by several authors (e.g. Baillie
Fig. 4 Recoveries of Eurasian Wrynecks (Jynx torquilla) on autumn migration: a ringed and recovered in the same season $(n=83)$; b ringed and recovered in different seasons $(n=38)$. Filled circle birds ringed and recovered in a later season are depicted with solid lines $(n=25)$; open circle birds recovered in a later season, yet attributed to inverse autumn migration are indicated with dashed lines $(n=13)$. Symbols indicate the recovery site. Test statistics of Rayleigh test 0.94 and 0.90 , respectively, $p<0.001$
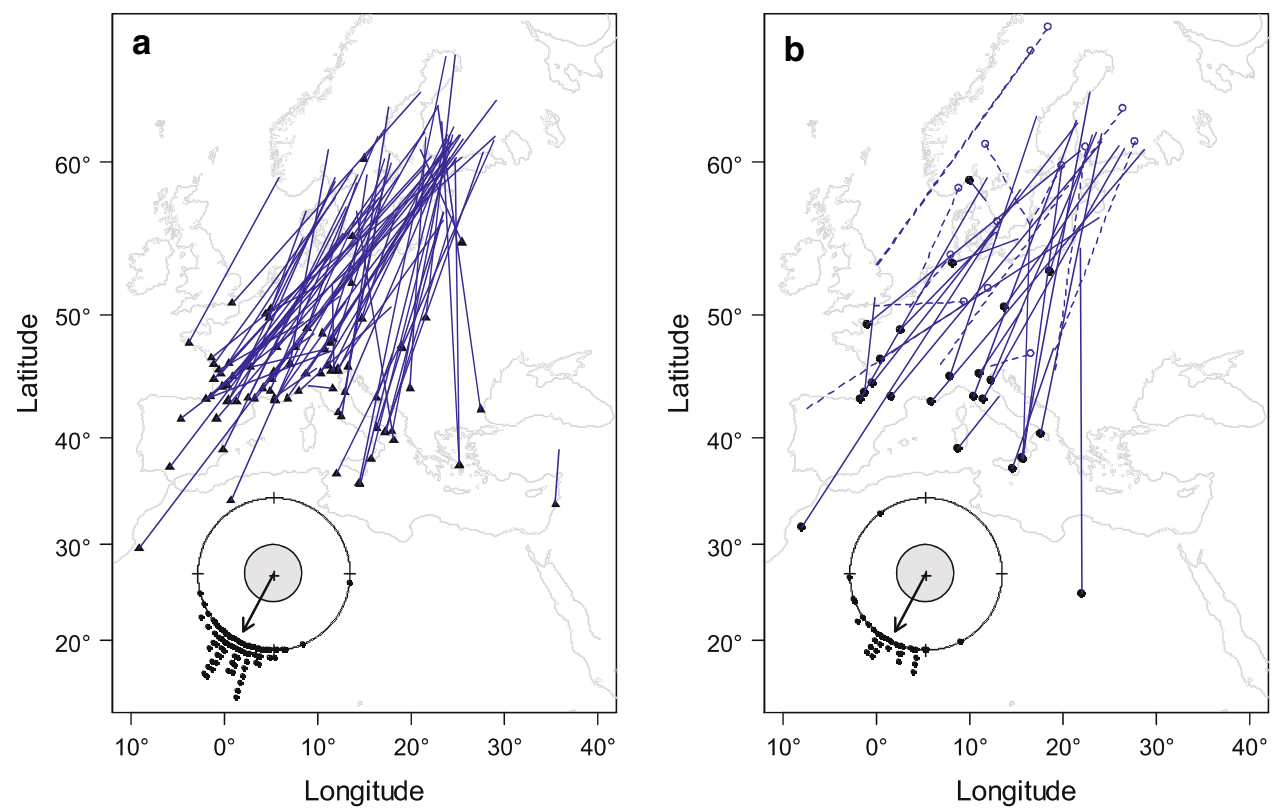


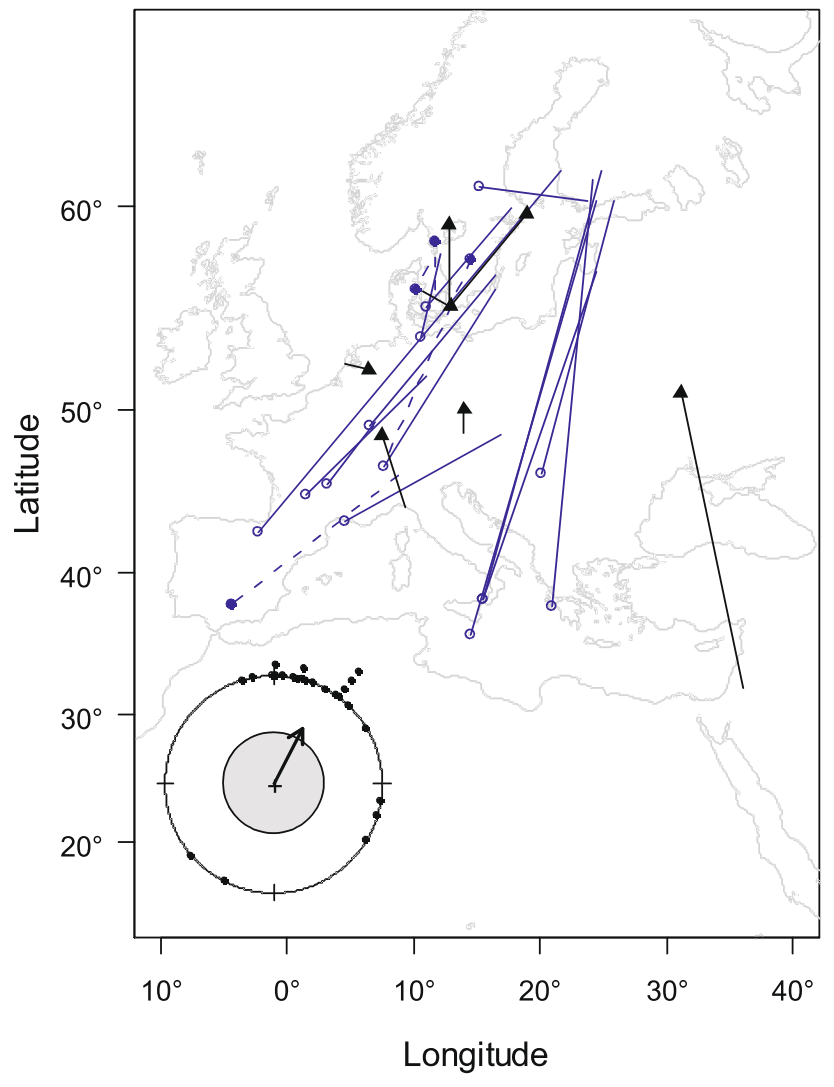

Fig. 5 Recoveries of Wryneck on spring migration. Filled triangle birds ringed and recovered in the same season $(n=7$, solid lines); filled circle birds ringed and recovered in a later season $(n=4$, dashed lines); open circle birds recovered in a later season, yet attributed to inverse spring migration (only recoveries with $>400 \mathrm{~km}$ between ringing and recovery site, $n=14$, solid lines). Symbols indicate the recovery site. Test statistics of Rayleigh test $0.69, p<0.001$

1995; Bairlein 2001). Information about migration patterns of the regionally threatened Wryneck and Hoopoe bear some conservation relevance. Although a substantial number of Hoopoes and Wrynecks have been ringed during the course of the last century (representative data for Germany and Switzerland: 8,643 Hoopoes, 19,665 Wrynecks), the number of recoveries remains scarce. This is due to the very low recovery rates (ca. $1.0 \%$ and $0.6 \%$ for Hoopoes and Wrynecks, respectively), with only one recovery (Hoopoe) available from the sub-Saharan wintering quarters. Hence, only indirect inferences about the location of wintering quarters of the different European breeding populations are possible.

Autumn migration

In contrast to previous suggestions (Glutz von Blotzheim and Bauer 1966), we found evidence of a migratory divide in Hoopoes (Fig. 1), with two distinct peaks in the distribution of migration directions (Fig. 1) as assessed by the circularlinear regression analysis (Fig. 2). We suggest that this divide lies between 10 and $12^{\circ} \mathrm{E}$, as the migration directions of Hoopoes ringed west and east of these longitudes, respectively, differ significantly. Generally, western European populations migrate to the Iberian Peninsula with directions around $225^{\circ}(\mathrm{SW})$, while eastern European populations migrate along the Balkan Peninsula [directions ca. $160^{\circ}$ (SSE); del Hoyo et al. 2001]. In addition to these two flyways, it seems that an intermediate zone also exists, where Hoopoes migrate south over Italy, possibly crossing the Mediterranean Sea over Calabria and Sicily.

No clear migratory divide was evident in Wrynecks, but a gradual shift in migration directions was apparent depending on the longitude of the ringing site. Birds ringed in western Europe show more westerly migration directions compared to birds ringed in eastern Europe. This contradicts previous views summarised in Glutz von Blotzheim and Bauer (1966) but supports earlier statements by Rendahl (1963) about Scandinavian Wrynecks: individuals ringed in Sweden chose a more westerly route than individuals from Finland. However, a migratory divide further to the east may still exist for this species. Ringing and recovery data from eastern and south-eastern Europe is needed to clarify this hypothesis.

We found two outliers in migration directions in the Hoopoe data (see Fig. 1a: at approximately $60^{\circ}$ and $290^{\circ}$ ): a bird 'migrating' to the east (nestling ringed in Switzerland, July 2005), and retrieved in Austria (August 2006), and a second bird 'migrating' to the north-west (ringed as after first-year bird in northern Italy, May 1994) and recovered at a distance of $180 \mathrm{~km}$ (northern Italy, September 1997). Possible explanations for this behaviour are: (1) the reverse migration hypothesis (e.g. Rabøl 1969; Thorup 2004), which states that, due to various reasons (Pfeifer et al. 2007), birds sometimes migrate $180^{\circ}$ opposite to the expected direction; or (2) natal and breeding dispersal, which can be over extremely long distances in migratory birds (Paradis et al. 1998). We favour the latter explanation because these two birds were recovered in a later year. As personal observations show, Hoopoes exhibit high breeding site fidelity after natal dispersal. The same explanation can apply to one Wryneck outlier, which was ringed as a second-year bird in May 1998 in Sweden and recovered in August of the following year in Norway (direction $320^{\circ}$; Fig. 4b). On other hand, a Wryneck captured and recaptured in northern Italy (May and October 1956, direction $100^{\circ}$; Fig. 4a) supports the hypothesis of a reverse migration.

Spring migration

Unfortunately, only very few same year recoveries were available. Thus, we combined all information on spring migration to describe migration directions. In both species, we found no indication that spring migration routes differed 
from autumn migration routes (Figs. 1, 3, 4 and 5, respectively), hence there is no indication for a loop-migration.

An outlier concerning migration directions in the Hoopoe data (ringed as nestling in Germany, June 1961, recovered on a freighter in the North Atlantic, April 1962) has already been mentioned in Seilkopf (1964), who suggested that this bird might have been diverted by the unusual atmospheric conditions and very strong winds. In the case of two Wrynecks which showed an intuitively wrong spring migration direction (approximately $110^{\circ}$ in the Netherlands and $120^{\circ}$ from Denmark to Sweden; see Fig. 5), we dismiss the reverse migration hypothesis. These two birds had been ringed in April and May, and recovered 1 and 14 days later, respectively. We suspect that these two birds were recovered rather early in their breeding area while they were still on the search for suitable breeding grounds.

\section{Wintering sites}

In the literature, wintering sites of Hoopoes and Wrynecks are described to be south of the Sahara Desert in the Sahel (Senegal to Ethiopia), with occasional overwintering in the Mediterranean area (Spain, Portugal and southern France), or northern Africa (Algeria, Morocco) (Glutz von Blotzheim and Bauer 1966; Cramp 1985; Fry et al. 1988; del Hoyo et al. 2001). Only one Hoopoe recovery was from within the described wintering areas (found in Niger). We therefore cannot delineate wintering grounds of these species based on the extant ring recoveries, and inferences on wintering areas are only possible by projecting (extrapolating) migration directions. As a result, only assumptions on the longitude of the wintering areas can be made, whereas inferences about latitude are impossible.

The directions from autumn migration indicate the usual pattern observed in other European long-distance migrants with comparable migration directions and documented wintering sites (Zink and Bairlein 1995). We suggest that west-European Hoopoes and Wrynecks are likely to winter in western Africa, while central- and east-European birds probably winter more in the east. This phenomenon would be more pronounced in the case of the Hoopoe, due to the migratory divide.

Despite using all available ring recoveries across Europe from almost one century, we were not able to make strong inferences about connectivity between breeding and wintering locations in Hoopoes and Wrynecks. Other methods, such as the use of stable isotopes in feathers (e.g. Hobson 1999; Procházka et al. 2008) or geo-data loggers (Phillips et al. 2007), appear to be promising approaches for inferring connectivity. We are currently applying these methods to populations in Switzerland and hope to be able to increase our knowledge about their wintering locations in the near future.

\section{Zusammenfassung}

Zugverhalten von Wiedehopf Upupa epops und Wendehals Jynx torquilla: Eine Analyse europäischer Ringfunde

Für viele Zugvogelarten sind Ringfunde die beste Quelle, um an Informationen über das Zugverhalten $\mathrm{zu}$ gelangen. In der vorliegenden Studie untersuchten wir Ringfunde von Wiedehopf und Wendehals zwischen 1914 und 2005, welche in der Europäischen Ringfundzentrale vorhanden sind. Das Ziel dieser Studie war die Beschreibung der Richtungen des Frühlings- und Herbstzuges, um Hinweise auf mögliche Überwinterungsorte $\mathrm{zu}$ bekommen. Beim Wiedehopf gibt es Anzeichen für eine Zugscheide in Zentraleuropa bei ungefähr $10-12^{\circ}$ östlichen Längengrades: Vögel, die östlich dieser Zugscheide brüten ziehen in südöstlicher Richtung ab, Vögel die westlich davon brüten in südwestlicher Richtung. Die Herbstzugrichtungen beim Wendehals ändern sich allmählich von südwestlicher zu südöstlicher Richtung in Abhängigkeit des Längengrades des Beringungsortes (West nach Ost). Bei beiden Arten gab es nur wenige Ringfunde, welche die Richtungen des Frühlingszuges anzeigten. Jedoch ähnelten die Frühlingszugrichtungen jenen vom Herbstzug und somit bestehen keine Hinweise auf einen Schleifenzug. Die wenigen Ringfunde aus Afrika lassen nur sehr limitierte Aussagen über die Winterquartier zu: Extrapolation der Zugrichtungen können den Längengrad des Winterquartiers anzeigen. Die Herbstzugrichtungen widerspiegeln ein typisches Zugverhalten Europäischer Langstreckenzieher: Wiedehopfe und Wendehälse aus Westeuropa überwintern wahrscheinlich in Westafrika, während Vögel aus Zentralund Osteuropa vermutlich mehr östlich überwintern. Dieses Phänomen ist beim Wiedehopf aufgrund der Zugscheide deutlicher ausgeprägt als beim Wendehals.

Acknowledgments We are indebted to the European Union for Bird Ringing (EURING), particularly Chris du Feu, EURING Data Bank Co-ordinator, and all European ringing schemes that provided the recovery data of Hoopoes and Wrynecks. We thank Wolfgang Fiedler (Vogelwarte Radolfzell, Germany) and Elisabeth Wiprächtiger (Swiss Ornithological Institute, Sempach) for providing additional data. We are grateful for the statistical and mathematical support provided by Fränzi Korner-Nievergelt and Fitsum Abadi Gebreselassie.

\section{References}

Baillie SR (1995) Uses of ringing data for the conservation and management of bird populations: a ringing scheme perspective. J Appl Stat 22:967-987. doi:10.1080/02664769524748

Baillie SR (2001) The contribution of ringing to the conservation and management of bird populations: a review. Ardea $89(\mathrm{Sp}$ Iss): $167-184$

Bairlein F (2001) Results of bird ringing in the study of migration routes. Ardea 89(Sp Iss):7-19 
Batschelet E (1981) Circular statistics in biology. Academic Press, London

Bibby CJ (2003) Conservation of migratory birds. In: Berthold P, Gwinner E, Sonnenschein E (eds) Avian migration. Springer, Berlin, pp 407-420

BirdLife International (2004) Jynx torquilla and Upupa epops. In: IUCN 2007 IUCN Red list of threatened species, available at http://www.iucnredlist.org

Cramp S (1985) Handbook of the birds of Europe, the Middle East, and North Africa. The birds of the Western Palearctic, vol 4. Terns to Woodpeckers. Oxford University Press, Oxford

del Hoyo J, Elliott A, Sargatal J (2001) Handbook of the birds of the world. Mousebirds to Hornbills, vol 6. Lynx, Barcelona

Fry CH, Keith S, Urban EK (eds) (1988) The birds of Africa, vol 3. Academic Press, London

Gauthier-Clerc M, Le Maho Y (2001) Beyond bird marking with rings. Ardea 89(Sp Iss):221-230

Glutz von Blotzheim UN, Bauer KM (1966) Handbuch der Vögel Mitteleuropas, vol Vol 9. Akademischer Verlag, Wiesbaden, Frankfurt am Main

Hobson KA (1999) Tracing origins and migration of wildlife using stable isotopes: a review. Oecologia 120:314-326. doi:10.1007/ s004420050865

Holmes RT (2007) Understanding population change in migratory songbirds: long-term and experimental studies of Neotropical migrants in breeding and wintering areas. Ibis 149(Suppl 2):213. doi:10.1111/j.1474-919X.2007.00685.x

Imboden C, Imboden D (1972) Formel für Orthodrome und Loxodrome bei der Berechnung von Richtung und Distanz zwischen Beringungs- und Wiederfundort. Vogelwarte 26:336-346

IUCN (2001) IUCN Red list categories and criteria. IUCN Species Survival Commission, Gland

Ketterson ED, Nolan VJ (1983) The evolution of differential migration. Curr Ornithol 1:357-402

Korner-Nievergelt F (2004) R codes for the calculation of migration directions and loxodromic distances between two points on the Earth, available at http://www.oikostat.ch

Norris DR, Wunder MB, Boulet M (2006) Perspectives on migratory connectivity. Ornithol Monogr 61:79-88

Pain DJ, Green RE, Giessing B, Kozulin A, Poluda A, Ottosson U, Flade M, Hilton GM (2004) Using stable isotopes to investigate migratory connectivity of the globally threatened aquatic warbler Acrocephalus paludicola. Oecologia 138:168-174. doi:10.1007/ s00442-003-1416-z

Paradis E, Baillie SR, Sutherland WJ, Gregory RD (1998) Patterns of natal and breeding dispersal in birds. J Anim Ecol 67:518-536. doi:10.1046/j.1365-2656.1998.00215.x

Pfeifer R, Stadler J, Brandl R (2007) Birds from the Far East in Central Europe: a test of the reverse migration hypothesis. J Ornithol 148:379-385. doi:10.1007/s10336-007-0140-6
Pfister C, Harrington BA, Lavine M (1992) The impact of human disturbance on shorebirds at a migration staging area. Biol Conserv 60:115-126

Phillips RA, Catry P, Silk JRD, Bearhop S, McGill R, Afanasyev V, Strange IJ (2007) Movements, winter distribution and activity patterns of Falkland and brown skuas: insights from loggers and isotopes. Mar Ecol Prog Ser 345:281-291. doi:10.3354/ meps06991

Procházka P, Hobson KA, Karcza Z, Kralj J (2008) Birds of a feather winter together: migratory connectivity in the Reed Warbler Acrocephalus scirpaceus. J Ornithol 149:141-150. doi:10.1007/ s10336-007-0250-1

Rabøl J (1969) Reversed migration as the cause of westward vagrancy by four Phylloscopus warblers. Br Birds 62:89-92

Rendahl H (1963) Über die Zugverhältnisse bei schwedischen Wendehälsen (Jynx torquilla L.). Arkiv Zoologi 16:315-329

Saurola P (1999) Rengastuksen juhlavuosi 1999 (Summary: Bird ringing in Finland 1999). Linnut-vuosikirja (1999) 67-78

Schüz E (1964) Zur Deutung der Zugscheiden des Weissstorchs. Vogelwarte 22:194-223

Seilkopf H (1964) Beringter Wiedehopf (Upupa epops) auf dem Nordatlantik. In: Drost R, Kuhk R, Goethe F, Schüz E (eds) Die Vogelwarte: Berichte aus dem Arbeitsgebiet der Vogelwarten Kommissionsverlagen Eugen Ulmer, Stuttgart, pp 178-180

Speek G, Clark JA, Rohde Z, Wassenaar RD, Van Noordwijk AJ (2006) The EURING exchange-code 2000. Dutch Ringing Center, Heteren

Szép T, Moller AP, Piper S, Nuttall R, Szabo ZD, Pap PL (2006) Searching for potential wintering and migration areas of a Danish Barn Swallow population in South Africa by correlating NDVI with survival estimates. J Ornithol 147:245-253. doi: 10.1007/s10336-006-0060-x

Thorup K (2004) Reverse migration as a cause of vagrancy. Bird Study 51:228-238

Walther BA, Schaffer N, van Niekerk A, Thuiller W, Rahbek C, Chown SL (2007) Modelling the winter distribution of a rare and endangered migrant, the Aquatic Warbler Acrocephalus paludicola. Ibis 149:701-714. doi:10.1111/j.1474-919X.2007.00690.x

Webster MS, Marra PP (2005) The importance of understanding migratory connectivity and seasonal interactions. In: Greenberg R, Marra PP (eds) Birds of two worlds: the ecology and evolution of migration. Johns Hopkins University, Baltimore, pp 199-209

Webster MS, Marra PP, Haig SM, Bensch S, Holmes RT (2002) Links between worlds: unraveling migratory connectivity. Trends Ecol Evol 17:76-83. doi:10.1016/S0169-5347(01)02380-1

Zink G, Bairlein F (1995) Der Zug europäischer Singvögel. Ein Atlas der Wiederfunde beringter Vögel, Aula, Wiesbaden 